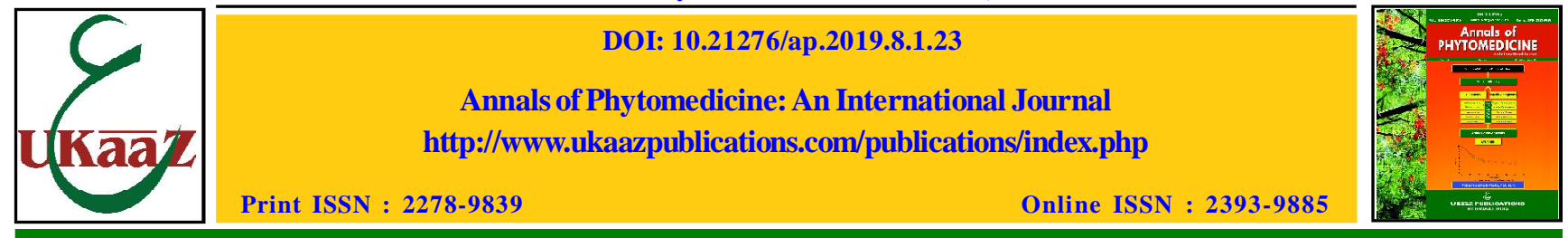

Original article

\title{
Pretreatment with trikatu augments pharmacokinetic profile and bioavailability of orally administered levofloxacin in goat
}

\author{
Jatin H. Patel*, Priti D. Vihol*, Kamlesh A. Sadariya***, Urvesh D. Patel**, Rasesh D. Varia, \\ Shailesh K. Bhavsar***, Ashwin M. Thaker*** and Jitendra K. Raval* \\ Department of Pharmacology and Toxicology, College of Veterinary Science and Animal Husbandry, Navsari \\ Agricultural University, Navsari-396450, Gujarat, India \\ *Department of Veterinary Pathology, College of Veterinary Science and Animal Husbandry, Navsari Agricultural \\ University, Navsari-396450, Gujarat, India \\ **Department of Pharmacology and Toxicology, College of Veterinary Science and Animal Husbandry, Junagadh \\ Agricultural University, Junagadh-362015, Gujarat, India \\ ***Department of Pharmacology and Toxicology, College of Veterinary Science and Animal Husbandry, Anand \\ Agricultural University, Anand-388 001, Gujarat, India
}

Received February 23, 2019: Revised April 13, 2019: Accepted April 15, 2019: Published online June 30, 2019

\begin{abstract}
Pharmacokinetics of levofloxacin in goats, following oral administration $(4 \mathrm{mg} / \mathrm{kg})$ was evaluated in trikatu pretreated goats. Reverse-phase High Performance Liquid Chromatography (HPLC) was applied for determination of levofloxacin concentration in plasma concentration. Maximum plasma concentration $\left(\mathrm{C}_{\max }\right)$, elimination halflife $\left(\mathrm{t}_{1 / 2 \beta}\right)$, volume of distribution $\left(\mathrm{Vd}_{\text {area }}\right)$, total body clearance $\left(\mathrm{Cl}_{\mathrm{B}}\right)$ and bioavailability were $0.60 \pm 0.03 \mu \mathrm{g} / \mathrm{ml}, 0.95$ $\pm 0.07 \mathrm{~h}, 1.91 \pm 0.11 \mathrm{l} / \mathrm{kg}, 1.06 \pm 0.06 \mathrm{l} / \mathrm{h} / \mathrm{kg}$ and $21.49 \%$, respectively observed after oral administration of levofloxacin in goats. In trikatu pretreated goats, pharmacokinetic parameters, viz., maximum plasma concentration $\left(\mathrm{C}_{\text {max }}\right)$, elimination half-life $\left(\mathrm{t}_{1 / 2 \beta}\right)$, volume of distribution $\left(\mathrm{Vd}_{\text {area }}\right)$, total body clearance $\left(\mathrm{Cl}_{\mathrm{B}}\right)$ and bioavailability were reported as $0.74 \pm 0.03 \mu \mathrm{g} / \mathrm{ml}, 2.07 \pm 0.15 \mathrm{~h}, 2.98 \pm 0.26 \mathrm{l} / \mathrm{kg}, 1.02 \pm 0.04 \mathrm{l} / \mathrm{h} / \mathrm{kg}$ and $30.16 \%$, respectively. In conclusion, significant difference was observed in majority of pharmacokinetic data of levofloxacin in trikatu pretreated goats than those in normal goats. Trikatu pretreatment in goats significantly increased bioavailability of levofloxacin.
\end{abstract}

Keywords: Pharmacokinetics, oral, levofloxacin, trikatu, goat

\section{Introduction}

Levofloxacin is a third-generation fluoroquinolone with a wide spectrum of bactericidal activity (Martinez et al., 2006). The drug is active against Gram-negative, Gram-positive and anaerobic bacteria including Pseudomonas species (Davis and Bryson, 1994). Pharmacokinetic studies of levofloxacin have been reported, following intravenous administration in cats (Albarellos et al., 2005), cow calves (Dumka and Srivastava, 2007a,b), horses (Goudah et al., 2008), camels (Goudah, 2009), chickens (Varia et al., 2009; Patel et al., 2012), sheep (Goudah and Hasabelnaby, 2010; Patel et al., 2012ab) and goats (Goudah and Abo-El-Sooud, 2009) and various in pharmacokinetics of the drug in different species have been observed. In addition to this, pharmacokinetic studies of levofloxacin have also been reported, following subcutaneous administration in sheep (Patel et al., 2012a) and calves (Dumka and Srivastava, 2007a,b; Ram et al., 2010). Moreover, pharmacokinetic studies of enrofloxacin and pefloxacin were performed in small

Author for correspondence: Dr. Jatin H. Patel

Assistant Professor, Department of Pharmacology and Toxicology, College of Veterinary Science and Animal Husbandry, Navsari Agricultural University, Navsari-396450, Gujarat, India

E-mail: drjatinvet@yahoo.co.in

Tel.: +91-9428489543

Copyright () 2019 Ukaaz Publications. All rights reserved.

Email: ukaaz@yahoo.com; Website: www.ukaazpublications.com ruminant to explore any possibility for oral administration in small ruminants like sheep and goats and it was found that bioavailability was ranged between 10 to $35 \%$ (Elmas et al., 2000; Malik et al., 2002). Pharmacokinetics of newer fluoroquinolone, marbofloxacin was also studied in chickens (Patel et al., 2019) as well as safety of morbofloxacin was evaluated in normal and piperine pretreated rats (Chauhan et al., 2017).

A number of scientific investigations have highlighted the importance and the contribution of many plants, i.e., Asteraceae, Liliaceae, Apocynaceae, Solanaceae, Caesalpinaceae, Rutaceae, Piperaceae and Sapotaceae for treatment of chronic conditions (Nayanabhirama, 2016) and herbal formulation found to be helpful in decreasing side effects of the drug (Bhadarka et al., 2018; Shaul et al., 2018). Herbal active constituent like piperine is proved to be helpful in modulating the disposition of drug (bioavailability) upon pretreatment or concomitant administration. Effects of bioenhancers are studied along with the drug having less bioavailability (Singh et al., 2009). Piperine (PIP), the major constituent obtained from the peppercorns of black pepper is used in anticonvulsant formulations in traditional Chinese medicine (Parveen et al., 2016). The plasma concentration of sodium valproate was significantly increased (11-fold) when it 
was given along with piperine (Parveen et al., 2016). Piperine (Piperaceae family) is content of trikatu formulation (Piper nigrum L., Piper longum L., Zingiber officinale Roscoe : 1:1:1) and known to have various effects, viz., enhance the permeation of drug through the epithelial barrier (Khajuria et al., 1998), inhibit the expression and functional activity of metabolic enzymes and drug transporters and, thus it has capacity to improve bioavailability of different drugs ranging from 30-200\% (Atal et al., 1985). In addition, levofloxacin was rapidly and almost completely absorbed after SC administration as shown in previous study (Patel et al., 2013). Looking to above facts, it was planned to determine the disposition kinetics and bioavailability of levofloxacin in goat, following oral administration alone and in trikatu pretreated goats.

\section{Materials and Methods}

\subsection{Experimental animals}

Six healthy female Surti non-lactating goats having body weight ranging from 30 to $35 \mathrm{~kg}$ were used in the experiment. The animals were obtained and maintained at the Instructional Farm, College of Veterinary Science and Animal Husbandry, Anand Agricultural University, Anand, India. They were kept under constant observation for two weeks, prior to commencement of the experiment and subjected to clinical examination to exclude the possibility of any disease. The animals were then housed in separate pen and were provided standard ration. Water was provided ad libitum. The experimental protocol (IAEC/VPT/63/2009) for general procedure and use of animals for conducting the present study has been approved by the Institutional Animal Ethics Committee of College of Veterinary Science and Animal Husbandry, Anand Agricultural University, Anand, Gujarat, India

\subsection{Drug and chemical}

Levofloxacin oral tablet $\left(250 \mathrm{mg}\right.$; Loxof ${ }^{\circledR}$, Ranbaxy Laboratories Ltd., Himachal Pradesh) was procured from local pharmacy. Levofloxacin technical grade powder was procured from Moxy Laboratory Pvt. Ltd., Gujarat, India. Acetonitrile, triethylamine, perchloric acid (70\%), ortho-phosphoric acid (min. 58\%) (Analytical grade) and water of HPLC grade were purchased from Merck Limited, Mumbai. Tikatu was purchased from Dhanvantri Pharma Ltd., Anand, Gujarat, India.

\subsection{Drug administration and sample collection}

Levofloxacin was administered at a dose rate of $4 \mathrm{mg} / \mathrm{kg}$ of body weight orally and randomly in six goats. Levofloxacin tablet $(250$ $\mathrm{mg}$ ) was dissolved in $25 \mathrm{ml}$ sterile water and used for oral administration using a syringe. Animals were fasted for $24 \mathrm{~h}$ before the oral administration of the drug. Pulverized trikatu was suspended in water and piperine equivalent to $20 \mathrm{mg} / \mathrm{kg}$ body weight was given orally through esophageal tube for 7 days (pretreatment) before administration of levofloxacin.

Blood samples $(2 \mathrm{ml})$ were collected through an intravenous catheter (Venflon, $22 \times 0.9 \times 25 \mathrm{~mm}$ ) fixed in the jugular vein in test tubes $\left(\mathrm{K}_{3}\right.$ EDTA $)$, prior to injection $(0 \mathrm{~h})$ and at $0.083,0.166,0.33,0.5$, $0.75,1,2,4,6,8,12$ and $18 \mathrm{~h}$ post-treatment after oral administration. Blood samples were subjected to centrifugation at $3000 \mathrm{~g}$ for $10 \mathrm{~min}$ and plasma samples were collected and preserved at $-20^{\circ} \mathrm{C}$, and analyzed within $48 \mathrm{~h}$ for determination of levofloxacin concentration.

\subsection{Analytical assay of levofloxacin}

Levofloxacin concentration in plasma samples was determined by reverse-phase High Performance Liquid Chromatography (HPLC) after extraction, using a reported assay (Varia et al., 2009) with minor modifications. The High Performance Liquid Chromatography (HPLC) apparatus (Laballiance, USA), comprised of quaternary gradient delivery pump (model AIS 2000), UV detector (model 500) and C18 column (Thermo ODS: $250 \times 4.6 \mathrm{~mm}$ ID) were used. Pharmacokinetic data integration was done by software 'Clarity' (Version 2.4.0.190).

Solution of pure enrofloxacin powder $(40 \mathrm{ml}$ of $0.5 \mu \mathrm{g} / \mathrm{ml}$ concentration) was utilized as an internal standard (IS). After addition of internal standard, each plasma sample $(500 \mu \mathrm{l})$, was deproteinized by addition of perchloric acid $(50 \mu \mathrm{l})$ and mixed on vortex for one minute. This was followed by centrifugation at $3000 \mathrm{~g}$ for $10 \mathrm{~min}$. An aliquot of supernatant was collected in clean vial and $20 \mu 1$ was injected into loop of HPLC system, using $50 \mu \mathrm{l}$ glass syringe (Hamilton Bonaduz AG, Switzerland). The mobile phase consisted of a mixture of $1 \%$ triethylamine in water and acetonitrile (85:15 v/ v), adjusted to $\mathrm{pH} 3.0$ with ortho-phosphoric acid. Mobile phase was filtered by $0.45 \mathrm{~m}$ size filter (Ultipor $\mathrm{N}_{66}$ Nylone 6, 6 membrane, PALL Pharma lab filtration Pvt., Ltd., Mumbai) and degassed by ultra-sonication. Thereafter, mobile phase was pumped into column at a flow rate of $1.5 \mathrm{ml} / \mathrm{min}$ at ambient temperature. The effluent was monitored at $290 \mathrm{~nm}$ wavelength.

Calibration curve was prepared daily for drug concentration ranging from 0.01 to $50 \mu \mathrm{g} / \mathrm{ml}$. The assay was sensitive (LLOD: $0.01 \mu \mathrm{g} /$ $\mathrm{ml}$ ), reproducible and linearity was observed from 0.01 to $50 \mu \mathrm{g} / \mathrm{ml}$ $\left(\mathrm{r}^{2}=0.99\right)$. The lower limit of quantification of the drug with a coefficient of variation of less than $8.36 \%$ was $0.01 \mu \mathrm{g} / \mathrm{ml}$. The mean extraction recovery from plasma was $>82.81 \pm 3.83 \%$ at the spiked concentrations between 0.01 and $50 \mu \mathrm{g} / \mathrm{ml}$. Precision and accuracy were determined using quality control (QC) samples at concentrations of $0.05,1,2.5,10$ and $50 \mu \mathrm{g} / \mathrm{ml}$ (5 replicates each per day). The intraday and interday coefficients of variation for 5 QC samples were satisfactory with the relative deviations (RSD) of less than $9.77 \%$.

\subsection{Calculation of pharmacokinetic parameters}

Pharmacokinetic parameters were calculated as per standard methods (Baggot, 1977; Gibaldi and Perrier, 1982). Absorption rate constant $\left(\mathrm{K}_{\mathrm{a}}\right)$ and elimination rate constant $(\beta)$ were calculated by least square regression analysis method. Absorption half-life $\left(\mathrm{t}_{1 / 2 \mathrm{ka}}\right)$ and elimination half-life $\left(\mathrm{t}_{1 / 2 \beta}\right)$ were calculated from $0.693 / \mathrm{K}_{\mathrm{a}}$ and $0.693 / \beta$, respectively. Maximum drug concentration in plasma $\left(\mathrm{C}_{\max }\right)$ and time of maximum observed concentration in plasma $\left(\mathrm{T}_{\max }\right)$ were obtained from actual plasma concentrations of rats. Area under curve $\left(\mathrm{AUC}_{(0-\infty)}\right)$ and area under the first moment of curve (AUMC) were calculated by linear trapezoidal rule. Apparent volume of distribution $\left(\mathrm{Vd}_{\text {area }}\right)$ was calculated from $($ Dose $\times \mathrm{F}) /(\beta \times \mathrm{AUC})$. The value of total body clearance $\left(\mathrm{Cl}_{\mathrm{B}}\right)$ was obtained using formula $\beta \times \mathrm{Vd}_{\text {(area) }}$. Mean residence time (MRT) was obtained by dividing the value of AUMC by AUC. The bioavailability (\%) was calculated as $\left(\mathrm{AUC}_{\text {Oral }} \times\right.$ Dose $\left._{\text {IV }}\right) \times 100 /\left(\right.$ AUC $_{\text {IV }} \times$ Dose $\left._{\text {Oral }}\right)$. Where, AUC after intravenous administration of levofloxacin in goat has been referred from our previous published study (Patel et al., 2018). 


\subsection{Statistical analysis}

Data of pharmacokinetic parameters of levofloxacin between both treatment groups were compared by students' ' $t$ ' test.

\section{Results}

No local or systemic adverse reactions were observed in clinical examination of all animals after the single-dose of levofloxacin and multiple treatment of trikatu in the animals studied. The chromatogram of the levofloxacin in plasma sample collected from goat under study is shown in Figure 1. The mean plasma drug concentrations after oral administration of levofloxacin $(4 \mathrm{mg} / \mathrm{kg})$ are presented in Table 1. The mean plasma concentration vs. time profile and pharmacokinetic parameters of levofloxacin $(4 \mathrm{mg} / \mathrm{kg})$ following oral administration of levofloxacin alone and in trikatu pretreated goats are presented in Figure 2 and Table 2, respectively.

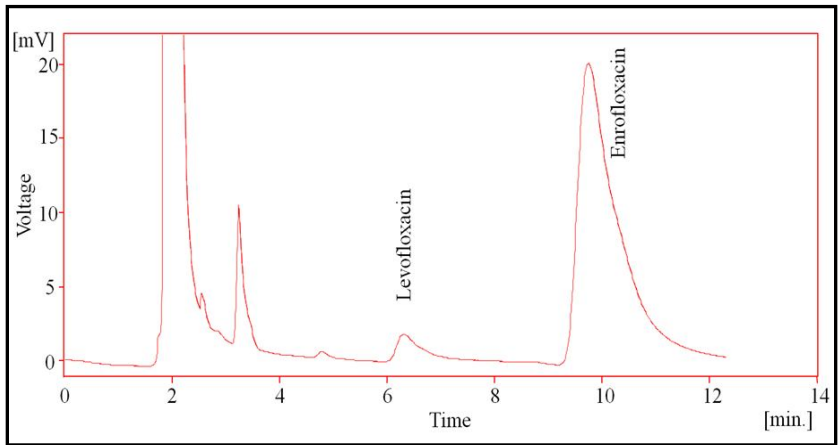

Figure 1: Representative chromatogram of levofloxacin in plasma after oral administration in goat $(4 \mathrm{mg} / \mathrm{kg})$ with enrofloxacin as IS.

Table 1: Plasma concentrations $(\mu \mathrm{g} / \mathrm{ml})$ of levofloxacin administered $(4 \mathrm{mg} / \mathrm{kg}$ ) in normal and trikatu pretreated goat following oral administration $(\mathrm{n}=6)$

\begin{tabular}{|c|c|c|}
\hline Time after drug & \multicolumn{2}{|c|}{ Plasma concentrations $(\boldsymbol{\mu g} / \mathrm{ml})$} \\
\cline { 2 - 3 } administration (h) & $\begin{array}{c}\text { Levofloxacin } \\
\text { alone }\end{array}$ & $\begin{array}{c}\text { Levofloxacin in trikatu } \\
\text { pretreated goat }\end{array}$ \\
\hline 0.5 & $0.07 \pm 0.01$ & $0.1 \pm 0.01$ \\
0.75 & $0.14 \pm 0.02$ & $0.24 \pm 0.01$ \\
1 & $0.26 \pm 0.02$ & $0.34 \pm 0.02$ \\
2 & $0.42 \pm 0.02$ & $0.51 \pm 0.03$ \\
4 & $0.60 \pm 0.03$ & $0.74 \pm 0.03$ \\
6 & $0.32 \pm 0.02$ & $0.39 \pm 0.02$ \\
8 & $0.07 \pm 0.01$ & $0.19 \pm 0.02$ \\
12 & ND & $0.05 \pm 0.01$ \\
\hline
\end{tabular}

ND: Not detected

Following oral administration of levofloxacin, peak plasma drug concentration $\left(\mathrm{C}_{\max }\right)$ of $0.60 \pm 0.03 \mu \mathrm{g} / \mathrm{ml}$ was observed at $4 \mathrm{~h}$ $\left(\mathrm{T}_{\max }\right)$. Following oral administration of levofloxacin in trikatu pretreated goats, plasma drug concentrations were found significantly higher at $0.5,0.75,1,2,4,6$ and $8 \mathrm{~h}$ in trikatu pretreated goat in comparison to normal goats (Table 1).

The area under curve and area under first moment curve following oral administration in normal goats was calculated to be $2.86 \pm 0.14$ $\mu \mathrm{g} . \mathrm{h} / \mathrm{ml}$ and $11.62 \pm 0.70 \mu \mathrm{g} . \mathrm{h}^{2} / \mathrm{ml}$, respectively. In trikatu pretreated goats, pharmacokinetic parameters like $\mathrm{t}_{1 / 2 \beta}(2.07 \pm 0.15), \mathrm{C}_{\max }(0.74$ $\pm 0.03 \mu \mathrm{g} / \mathrm{ml}), \mathrm{AUC}_{0-\infty}(4.15 \pm 0.10 \mu \mathrm{g} \cdot \mathrm{h} / \mathrm{ml}), \operatorname{AUMC}(20.53 \pm 0.65$ $\left.\mu \mathrm{g} . \mathrm{h}^{2} / \mathrm{ml}\right), \mathrm{Vd}_{\text {area }}(2.98 \pm 0.26 \mathrm{l} / \mathrm{kg})$, MRT $(4.95 \pm 0.15 \mathrm{~h})$, MAT $(2.41$ $\pm 0.33 \mathrm{~h})$ and bioavailability $(30.16 \pm 1.31 \%)$ were significantly higher in comparison to normal goat.

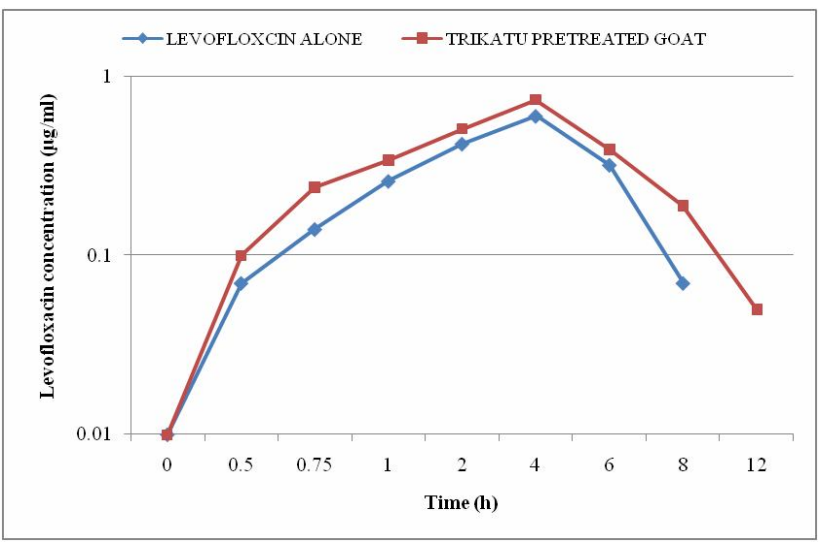

Figure 2: Plasma concentration vs. time profile of levofloxacin $(4 \mathrm{mg} / \mathrm{kg}$, orally) in normal and tirkatu pretreated goat $(n=6)$.

Table 2: Pharmacokinetic parameters (Mean \pm SE) of levofloxacin (at a dose rate of $4 \mathrm{mg} / \mathrm{kg}$ of body weight) in normal and tirkatu pretreated goat after oral administration $(n=6)$

\begin{tabular}{|c|c|c|c|}
\hline $\begin{array}{c}\text { Pharmacokinetic } \\
\text { parameter }\end{array}$ & Unit & Levofloxacin & $\begin{array}{c}\text { Trikatu } \\
\text { pretreatment }+ \\
\text { levofloxacin }\end{array}$ \\
\hline $\mathrm{K}_{\mathrm{a}}$ & $\mathrm{h}^{-1}$ & $0.92 \pm 0.04$ & $0.88 \pm 0.13$ \\
$\beta$ & $\mathrm{h}^{-1}$ & $0.75 \pm 0.07$ & $0.34 \pm 0.02 * *$ \\
$\mathrm{t}_{1 / \mathrm{Ka}}$ & $\mathrm{h}$ & $0.76 \pm 0.03$ & $0.88 \pm 0.13$ \\
$\mathrm{t}_{1 / \beta}$ & $\mathrm{h}$ & $0.95 \pm 0.07$ & $2.07 \pm 0.15^{* *}$ \\
$\mathrm{C}_{\max }$ & $\mu \mathrm{g} / \mathrm{ml}$ & $0.60 \pm 0.03$ & $0.74 \pm 0.03^{* *}$ \\
$\mathrm{~T}_{\max }$ & $\mathrm{h}$ & $4.00 \pm 0.00$ & $4.00 \pm 0.00$ \\
$\mathrm{AUC}_{0-\infty}$ & $\mu \mathrm{g} . \mathrm{h} / \mathrm{ml}$ & $2.86 \pm 0.14$ & $4.15 \pm 0.10^{* *}$ \\
$\mathrm{AUMC}$ & $\mu \mathrm{g} . \mathrm{h}^{2} / \mathrm{ml}$ & $11.62 \pm 0.70$ & $20.53 \pm 0.65^{* *}$ \\
$\mathrm{Vd}_{\text {area }}$ & $1 / \mathrm{kg}$ & $1.91 \pm 0.11$ & $2.98 \pm 0.26^{* *}$ \\
$\mathrm{Cl}_{\mathrm{B}}$ & $1 / \mathrm{h} / \mathrm{kg}$ & $1.06 \pm 0.06$ & $1.02 \pm 0.04$ \\
$\mathrm{MRT}$ & $\mathrm{h}$ & $4.05 \pm 0.09$ & $4.95 \pm 0.15^{* *}$ \\
$\mathrm{MAT}_{\mathrm{F} T}$ & $\mathrm{~h}$ & $1.51 \pm 0.23$ & $2.41 \pm 0.33^{* *}$ \\
$\mathrm{~F}$ & $\%$ & $21.49 \pm 1.60$ & $30.16 \pm 1.31^{* *}$ \\
\hline
\end{tabular}

* Significant with $p<0.05$;* Significant with $p<0.01$; Ka, absorption rate constant; $\beta$, elimination rate constant; $t_{1 / 2 k(a)}$, absorption halflife; $\mathrm{t}_{1 / 2 \beta}$, elimination half-life; $\mathrm{C}_{\max }$, maximum drug concentration; $\mathrm{T}_{\max }$, time to peak plasma drug concentration; $\mathrm{AUC}_{(0-\infty)}$, area under the curve from zero to infinity; AUMC, area under first of moment curve; $\mathrm{Vd}_{\text {area }}$, apparent volume of distribution; $\mathrm{Cl}_{\mathrm{B}}$, total body clearance; MRT, mean residence time; F, bioavailability.

\section{Discussion}

Following oral administration of levofloxacin, peak plasma drug concentration $\left(\mathrm{C}_{\max }\right)$ was found in proximate to $\mathrm{C}_{\max }$ of enrofloxacin $(0.25 \pm 0.03 \mu \mathrm{g} / \mathrm{ml})$ observed following oral administration in goats (Elmas et al., 2000). However, higher value of $\mathrm{C}_{\max }$ of pefloxacin 
$(2.22 \pm 0.48 \mu \mathrm{g} / \mathrm{ml})$ was reported following oral administration in goats (Malik et al., 2002). Time at which maximum plasma concentration observed in present study was $4 \mathrm{~h}$ and similar observations were reported with oral enrofloxacin in goats with $\mathrm{t}_{\max }: 5.20 \pm 1.20 \mathrm{~h}$ (Elmas et al., 2000), $5.5 \mathrm{~h}$ in sheep (Berminghan, 2002) and $4.0 \mathrm{~h}$ in Nemorhaebus goral (Rae Gandolf et al., 2006). Time at which maximum plasma concentration of marbofloxacin after oral administration in buffalo calves was observed 0.5 to $6.0 \mathrm{~h}$ (Baroni et. al., 2007) which shows wide variation in $\mathrm{t}_{\max }$ of fluoroquinolones in ruminants may be due to complex ecosystem of rumen. Values of AUC following oral administration of enrofloxacin $(4.92 \pm 0.52 \mu \mathrm{g} . \mathrm{h} / \mathrm{ml})$ and pefloxacin $(10.48 \pm 1.31$ $\mu \mathrm{g} . \mathrm{h} / \mathrm{ml}$ ) in goats (Elmas et al., 2000; Malik et al., 2002) were reported higher than the AUC found in present study. Elimination half-life of levofloxacin reported in goats $(0.95 \pm 0.07 \mathrm{~h})$ was observed lower than elimination half-life of enrofloxacin (9.26 \pm $0.65 \mathrm{~h})$ and pefloxacin $(2.91 \pm 0.50 \mathrm{~h})$, following oral administration (Elmas et al., 2000; Malik et al., 2002). The mean apparent volume of distribution $\left(\mathrm{Vd}_{\text {area }}\right)$ after oral administration of levofloxacin was found lower $(1.91 \pm 0.11 \mathrm{l} / \mathrm{kg})$ in goats in comparison to pefloxacin $(3.63 \pm 0.89 \mathrm{l} / \mathrm{kg}$ ) in goats (Malik et al., 2002). The total body clearance of levofloxacin observed in the present study in goats was found higher to the clearance of enrofloxacin $(0.24 \pm 0.01 \mathrm{l} / \mathrm{h} /$ $\mathrm{kg})$ and pefloxacin in goats $(0.82 \pm 0.08 \mathrm{l} / \mathrm{h} / \mathrm{kg})$, following its oral administration (Elmas et al., 2000; Malik et al., 2002).

The bioavailability (F) of the levofloxacin ranged from 19 to $25 \%$ with an average of $21.49 \pm 1.60 \%$. However, higher bioavailability of pefloxacin was reported in goats $(42.42 \pm 5.83 \%)$ and enrofloxacin in cow calves $(66.0 \pm 7.0 \%)$ (Malik et al., 2002; Sharma and Varshney, 2009). Following oral administration, levofloxacin is poorly bioavailable with low distribution and high clearance rate. In support, it was reported that about $80 \%$ of an orally administered dose of levofloxacin in human was found in the urine as unchanged and $\leq 5 \%$ as inactive metabolites (Fish and Chow, 1997).

In general, fluoroquinolones are well absorbed following oral administration, with bioavailability for most agents in excess of 85 per cent in human but less bioavailability in ruminants. Serum drug levels achieved with the other fluoroquinolones (levofloxacin, moxifloxacin, and ofloxacin), after oral administration are comparable to concentrations achieved with intravenous (IV) dosing. This allows for early transition from IV to oral therapy and potential reduction of treatment costs (Walker, 1999). Levofloxacin is widely distributed throughout the body with satisfactory tissue concentrations. The drug is mainly excreted through renal route of drug excretion (Patel et al., 2012a). Absorption of levofloxacin following oral administration in poultry was satisfactory but anatomical and physiological factors in ruminant creates barrier for absorption of the drug from rumen in animals (Varia et al., 2009; Patel et al., 2012). Levofloxacin, levo isomer of ofloxacin (Wimer et al., 1998), shows its pharmacological activities by altering DNA of bacteria causes death by decreasing or blocking the activity of gyrase and topoisomerase. Like many other antimicrobial drugs, levofloxacin's antimicrobial activity is concentration dependent. The bactericidal activity increases as the increase in the concentration of the drug at the site of infection.
Plasma drug concentrations were observed significantly higher in trikatu pretreated goats in present study and similar results were observed in Gaddi goats, following oral administration of pefloxacin (Dama et al., 2008). In rabbits also, significant higher level of peak plasma concentration of norfloxacin in piperine treated group (17.78 $\pm 0.32 \mu \mathrm{g} / \mathrm{ml})$ than norfloxacin alone group $(7.07 \pm 0.26 \mu \mathrm{g} / \mathrm{ml})$ at $2 \mathrm{~h}$ was observed (Janakiraman and Manavalan, 2008). In this context, piperine is content of trikatu formulation (P. nigrum, P. longum, Z. officinale: 1:1:1) and known to enhance the permeation of drug through the epithelial barrier (Khajuria et al., 1998) and inhibit the expression and functional activity of metabolic enzymes and drug transporters and, thus it has capacity to improve bioavailability of different drugs ranging from 30-200\% (Atal et al., 1985). The piperine has reduced the rate of drug elimination and significantly increased the elimination half-life. Significant increased AUC value of levofloxacin in trikatu pretreated animals indicates increase in efficacy of the drug against susceptible bacteria which may have higher MIC values. P-glycoprotein (P-gp) is a protein encoded by multidrug resistance gene (MDR1). It belongs to ATPbinding cassette transporter superfamily (ABC). P-gp is localized in the cell-membrane and plays an important role in the transmembrane efflux of variety substances including drugs and toxins. The inhibition of P-gp by piperine in the study may be the reason for reduction in excretion of the drug (Kim et al., 2018), which led to high concentration of the drug in piperine pretreated animals.

\section{Conclusion}

Looking to pharmacokinetic parameters of levofloxacin in goats, drug is poorly bioavailable after oral administration due to higher clearance rate and lower elimination half life. In trikatu pretreated goats, maximum plasma concentration was significantly improved by 23 per cent. Most pharmacokinetic parameters, following oral administration of levofloxacin were significantly higher in trikatu pretreated goats than those observed in normal goats. Trikatu treatment statistically increases bioavailability of levofloxacin which may be due to known herbal bioenhancer piperine present in the triherb mixture used in the study but, practically it seems to be increased only 9 percent.

\section{Acknowledgments}

Authors are thankful to College of Veterinary Science and Animal Husbandry, Anand Agricultural University, Anand, Gujarat, India for providing infrastructure facilities for completion of this study.

\section{Conflict of interest}

The authors declare that no conflict of interest exists in the course of conducting this research. All authors had final decision regarding the manuscript and the decision to submit the findings for publication.

\section{References}

Abdullah, A.; Khan, M.; Ahmad, W.; Ahmad, M. and Nisar, M. (2017). Hepatoprote ctive effect of the solvent extract of Viola canescens Wall. Ex. Roxb. against $\mathrm{CCl}_{4}$ induced toxicity through antioxidant and membrane stabilizing activity. BMC Complementary and Alternative Medicine, 17:10-21. 
Albarellos, G.A., Ambros, L.A. and Landoni, M.F. (2005). Pharmacokinetic of levoûoxacin after single intravenous and repeat oral administration to cats. Journal of Veterinary Pharmacology Therapeutics, 28:363-369.

Atal, C.K.; Dubey, R.K. and Singh, J. (1985). Biochemical basis of enhanced drug bioavailability by piperine: Evidence that piperine is a potent inhibitor of drug metabolism. Journal of Pharmacology and Experimental Therapeutics, 232(1):258-262.

Baroni, E.E.; Rubio, S.; Diaz, D.C.; Crudeli, G.; de Lucas, J.J.; Rodriguez, C. and San Andres, M.I. (2007). Pharmacokinetics of marbofloxacin, after one bolus oral administration in buffaloes calves: Preliminary study. Italian Journal of Animal Science, 6(2):835-837.

Berminghan, E.C. (2002). Pharmacokinetics after intravenous and oral administration of enrofloxacin in sheep. American Journal of Veterinary Research, 63(7):1012-1017.

Bhadarka, D.H.; Patel, U.D.; Shaul Ahmed; Patel, H.B.; Modi, C.M. and Fefar, D.T. (2018). Biochemical and histologic evaluation following multiple dose administration of paracetamol alone and along with polyherbal extract mixture in rats. Ann. Phytomed., 7(2):114-123.

Chauhan, V.B.; Modi, C.M.; Patel U.D.; Patel, H.B.; Kalaria V.A.; Fefar, D.T.; Bhadarka, D.H., Solanki, S.L and Shaul Ahmed. (2017). Safety profile of marbofloxacin following repeated intramuscular administration alone and piperine pretreated rats. Ann. Phytomed., 6(2):88-92.

Dama, M.S.; Varshneya, C.; Dardi, M.S. and Katoch, V.C. (2008). Effect of trikatu pretreatment on the pharmacokinetics of pefloxacin administered orally in mountain Gaddi goats. Journal of Veterinary Science, 9(1):25-29.

Davis, R. and Bryson, H.M. (1994). Levofloxacin: A review of its antibacterial activity, pharmacokinetics and therapeutic efficacy. Drugs, 47:677-700.

Dumka, V.K. and Srivastava, A.K. (2007a). Kinetic disposition, urinary excretion and dosage regimen of subcutaneously administered levofloxacin in cross bred calves. Iranian Journal of Veterinary Research, 8:313-318

Dumka, V.K. and Srivastava, A.K. (2007b). Disposition kinetics, urinary exeretion and dosage regimen of levofloxacin formulation following single intravenous administration in crossbred calves. Veterinary Research Communications, 31:873-879.

Elmas, M.; Yazar, E.; Tras, B.; Bas, A. L. and Eryavuz, A. (2000). Pharmacokinetics and oral bioavailability of enrofloxacin in faunated and defaunated Angora goats. The Revue de Medecine Veterinaire, 51(6):507-510.

Fish, D.N. and Chow, A.T. (1997). The clinical pharmacokinetics of levofloxacin. Clinical Pharmacokinetics, 32(2):101-119.

Goudah, A. (2009). Pharmacokinetics of levofloxacin in male camels (Camelus dromedarius). Journal of Pharmacology and Experimental Therapeutics, 2:296-299.

Goudah, A. and Abo-El-Sooud, K. (2009). Pharmacokinetics, urinary excretion and milk penetration of levofloxacin in lactating goats. Journal of Veterinary Pharmacology Therapeutics, 32:101-104.

Goudah, A. and Hasabelnaby, S. (2010). Disposition kinetics of levofloxacin in sheep after intravenous and intramuscular administration. Veterinary Medicine International, pp:1-6.

Goudah, A.; Abo El-Sooud, K.; Shim, J.H.; Shin, H.C. and Abd El-Aty, A.M.; (2008). Characterization of the pharmacokinetic disposition of levofloxacin in stallions after intravenous and intramuscular administration. Journal of Veterinary Pharmacology Therapeutics, 31:399-405.
Janakiraman, K. and Manavalan, R. (2008). Studies on effect of piperine on oral bioavailability of ampicillin and norfloxacin. The African Journal of Traditional, Complementary and Alternative Medicines, 5(3):257-262.

Khajuria, A.; Zutshi, U. and Bedi, K.L. (1998). Permeability characteristics of piperine on oral absorption an active alkaloid from peppers and a bioavailability enhancer. Indian Journal of Experimental Biology, 36(1):46-50.

Kim, T.H.; Shin, S; Yoo, S.D. and Shin, B.S. (2018). Effects of phytochemical P-Glycoprotein modulators on the pharmacokinetics and tissue distribution of doxorubicin in mice. Molecules, 23:1-14.

Malik, J.K.; Rao, G.S.; Ramesh, S.; Muruganandan, S.; Tripathi, H.C. and Shukla, D.C. (2002). Pharmacokinetics of pefloxacin in goats after intravenous and oral administration. Veterinary Research Communications, 26:141-149.

Martinez, M.; P. McDermott, and Walker, R. (2006). Pharmacology of the fluoroquinolones: A perspective for the use in domestic animals. Veterinary Journal, 172:10-28.

Parveen, B.; Ahmad, S. and Pillai, K.K. (2016). In vivo activity and pharmacokinetic analysis of combination of piperine and subtherapeutic dose of sodium valproate in refractory epilepsy. Ann. Phytomed., 5(1):73-79.

Patel, H.B.; Patel, U.D.; Modi, C.M.; Shaul Ahmed and Solanki, S.L. (2019). Pharmacokinetic profiles of marbofloxacin following single and repeated oral administration in broiler chickens. Ann. Phytomed., 7(2): $174-179$.

Patel, J.H.; Varia, R.D.; Vihol, P.D.; Ratndeep, S.; Patel, U.D.; Bhavsar, S.K.; and Thaker, A.M. (2012). Pharmacokinetics and bioavailability of levofloxacin in white leg horn birds. Indian Veterinary Journal, 89(8):69-71

Patel, J.H.; Vihol P.D.; Patel U.D.; Bhavsar S.K. and Thaker A.M. (2013). Pharmacokinetics of levofloxacin following subcutaneous administration in goat. Journal of Veterinary Pharmacology and Toxicology, 12(1-2):35-38.

Patel, J.H.; Vihol, P.D.; Sadariya K.A.; Patel U.D.; Varia R.D.; Bhavsar S.K. and Thaker A.M. (2018). Effect of ketoprofen co-administration and febrile state on pharmacokinetics of levofloxacin in goats following intravenous administration. International Journal of Current Microbiology and Applied Sciences, 7(10):2477-2483.

Patel, U.D.; Patel, J.H.; Bhavsar, S.K. and Thaker, A.M. (2012a). Pharmacokinetics of levofloxacin following intravenous and subcutaneous administration in sheep. Asian Journal of Animal and Veterinary Advances, 7:85-93.

Patel, U.D.; Patel, J.H.; Varia, R.D.; Patel, H.B; Bhavsar, S.K. and Thaker, A.M. (2012b). Disposition kinetic of levofloxacin in experimentally induced febrile model of sheep. Journal of Pharmacology and Toxicology, 7(1):11-19.

Rae Gandolf, A.; Papich M.G.; Bringardner, A. B. and Atkinson, M.W. (2006) Single dose intravenous and oral pharmacokinetics of enrofloxacin in goral (Nemorrhaebus Goral Aronouxianus). Journal of Zoo and Wildlife Medicine, 37(2):145-150.

Ram, D.; Dumka, V.K.; Sandhu, H.S. and Raipuria, M. (2010). Pharmacokinetics and dosage regimen of levofloxacin in buffalo calves after single subcutaneous administration. Veterinarski Arhiv., 80:195-203.

Sharma, A.K. and Varshneya, C. (2009). Pharmacokinetics of enrofloxacin following oral administration in pre-ruminant cow calves and its modulation by pretreatment of Trikatu, A herbal bio-enhancer. In: Compedium of IX Annual conference of Indian Society of Veterinary Pharmacology and Toxicology during 5-7 November, pp:249. 
Shaul A.; Patel, U.D.; Bhadarka, D.H.; Patel, H.B. and Modi, C.M. (2018). Biochemical and histologic evaluation following multiple dose administration of paracetamol alone and along with polyherbal extract mixture in rats. Ann. Phytomed., 7(2):102-113.

Singh, Ratndeep; Sarita Devi; Patel, J.H.; Patel, U.D.; Bhavsr, S.K. and Thaker, A.M. (2009). Indian Herbal Bioenhancers: A review. Pharmacognosy Review, 3(5):80-82.

Nayanabhirama U. (2016). Status on herbal drugs and their future properties. Ann. Phytomed., 5(1):1-3.
Varia, R.D.; Patel, J.H.; Patel, U.D.; Bhavsar, S.K. and Thaker, A.M. (2009). Disposition of levofloxacin following oral administration in broiler chickens. Israel Journal of Veterinary Medicine, 64:118-121.

Walker, R.C. (1999). The fluoroquinolones. Mayo Clinical Proceedings, 74:1030-1037.

Wimer, S.M.; Schoonover, L. and Garrison, M.W. (1998). Levofloxacin: A therapeutic review. Clinical Therapeutics, 20(6):1049-1070.

Citation: Jatin H. Patel, Priti D. Vihol, Kamlesh A. Sadariya, Urvesh D. Patel, Rasesh D. Varia, Shailesh K. Bhavsar, Ashwin M. Thaker and Jitendra K. Raval (2019). Pretreatment with trikatu augments pharmacokinetic profile and bioavailability of orally administered levofloxacin in goat. Ann. Phytomed., 8(1):172-177. 